$\langle$ Review〉

\title{
Cultural Landscape and Ecotourism in Bali Island, Indonesia
}

\author{
Hakim, Luchman', Jae-Eun $\mathrm{Kim}^{2}$ and Sun-Kee Hong ${ }^{2 *}$ \\ ${ }^{1}$ Department of Biology, Brawijaya University, Jl. Veteran Malang 65145, East Java, Indonesia \\ ${ }^{2}$ Institute of Island Culture, Mokpo National University, Jeonnam 534-729, Korea
}

\begin{abstract}
This paper describes the role of ethnoecology in supporting tourism. We conducted a case study on the island of Bali (Indonesia), the famous tourism destination. We review the culture, nature and ecotourism prospects of Bali and then extend our discussion to examine the role of indigenous philosophies in building the destination's image. Bali has a rich culture and natural resources that have been utilized and managed through an indigenous philosophy called Tri Hita Karana. Ethnoecology is widely applied and appreciated in the society and has produced Balinese cultural landscapes that have become significant tourism attractions. There has been a recent increase in tourist desire to explore genuine Balinese culture, so ethnoecology has a significant role in the quest to preserve and conserve such indigenous cultural landscapes. Ethnoecology is a key to ensuring and sustaining the images and authenticity of Bali Island. In this paper, we considered the landscape of rice paddies as a cultural landscape and resource for tourism. The structure and function of paddy terrace landscapes is based on the ethnoecology of Tri Hita Karana; therefore, in order to understand nature and ecotourism in Bali Island, knowledge of indigenous philosophy is indispensable. Cultural landscapes that link human and natural systems are not only places of natural beauty but also provide background information about the history of human adaptations to nature.
\end{abstract}

Key words: Authenticity, Bali Island, Cultural ecology, Ecotourism, Ethnoecology, Sustainable development

\section{INTRODUCTION}

Issues surrounding the sustainability and competitiveness of the tourism industry have been discussed extensively by scholars and tourism planners. The term "sustainable tourism" is emerging in every corner of the world and is pertinent to the sustainable development agenda. There are three foundations for planning and achieving sustainable development in every sector of development, namely economic, environmental and socio-cultural components, which should in balance. Sustainable tourism therefore maximizes economic earnings while helping to support environmental and resource conservation, as well as cultural preservation (TIES 2000, Gunn and Var 2002, Swarbrooke 2006, Hakim et al. 2007, 2008, Hakim 2008).

The World Tourism Organization reports that tourism continuous to grow significantly, particularly in areas that are rich in biodiversity but often environmentally and culturally fragile (UNWTO 2007). The increasing demands of tourism have led to the establishment of new tourism destinations, re-actualization of heritages, projects to increase the quality of the environment, and efforts to provide excellent services in order to meet tourist satisfaction. Today, many studies focus on tourism destinations, reflecting on the importance of such sectors in the tourism system. Planners and developers de- fine a destination as a region or area where there is significant potential for tourism. Scholars have found that planning is a prerequisite to enhance destination competitiveness and sustainability. According to Baud-Bovy and Lowson (2002), appropriate planning must provide a general master plan related to land use and basic infrastructure to meet tourist demands. In particular, much attention is usually paid to the attraction itself, since the attraction is the core of the destination.

Scholars reveal that attractions, based on natural and social-cultural phenomena, are the heart of destinations (Fyall et al. 2005, Swarbrooke 2006). Tourists come to a particular destination because they want to interact with the attraction. Considering the importance of the attraction, many technical guidelines for attraction management have been proposed and implemented. Mostly these are object-oriented, such as guidelines for heritage management, habitat management, flora management and wildlife handling (Baud-Bovy and Lowson 2002). In developing countries, however, the way in which attraction occurs and evolves is rarely discussed. Planners often view attractions as natural phenomena and neglect the role of humans in creating an attraction.

Exploring local people's contributions to a tourism destination should be a prerequisite for sustainable tourism, particularly if the destination's characteristics are associated with local culture and

* Corresponding author; Phone: +82-10-4312-3738, e-mail: skhong@mokpo.ac.kr, landhong@yahoo.co.kr 
traditions (Hakim 2008). Understanding how local people interact with nature and create attractions will allow tourism planners to develop planning scenarios to enhance and ensure the sustainability and competitiveness of tourism destinations. This implies, besides applying a technological approach, using ethnoecology as a tool to understand how local people interact with nature and create attractions. According to Martin (1995), ethnoecology is emerging as a multidisciplinary science examining the relationship between the local indigenous community and nature, and nowadays it has potential to contribute to the sustainability of the biosphere. Ethnoecology can allow planners and developers to develop scenarios in an "indigenous-friendly" manner and represent the genuine nature of the destination, as well as minimize the misrepresentation of destinations.

In this paper, we review how ethnoecology may help planners to establish a sustainable tourism destination. Using Bali Island as a case study, this paper begins with a discussion of the nature, culture and tourism in Bali, and provides general information about Bali Island as a tourist destination. Then, we examine the cultural landscape of Bali and indigenous philosophy, and the role of ethnoecology in supporting regional authenticity in tourism. Our discussion of the case of Bali provides an example of how local traditions contribute to a destination's sustainability and competitiveness.

\section{NATURE, CULTURE AND TOURISM IN BALI}

Many brochures, magazines, and websites introduce and describe Bali as a piece of heaven on earth. Bali Island is situated east of Java and the west of the Lesser Sunda Islands in the Indonesia archipelago. The island covers an area of $5,632.86 \mathrm{~km}^{2}$ and is the primary home of the Hindu community in Indonesia. Administratively, the whole area is divided into seven regencies, namely, Badung, Gianyar, Klungkung, Bangli, Karangasem, Jembrana and Buleleng and Denpasar city (Whitten et al. 1996, Pemprov Bali 2006, Picard 2006).

The island is flanked by the Bali Strait to the west, the Java Sea to the north, the Lombok Strait to the east and the Indian Ocean to the south (Fig. 1). The marine ecosystems surrounding Bali are diverse, ranging from sea grasses to amazing coral reefs. Among the hot spots for coral reefs and marine creatures are Menjangan Island and Pemuteran in the north, Nusa Penida and Nusa Lembongan in the south and Gili Tepekong, Gili Biaha, Gili Mimpang, Amed and Tulamben in the east. The south coastal coast has nesting sites for sea turtles and numerous marine creatures, making the Bali coastal and marine region one of the leading world's biodiversity hot spots.

Bali is mostly a volcanic island, located in the Sunda volcanic arc. Two mountains remain active in the center of island: Mt Agung

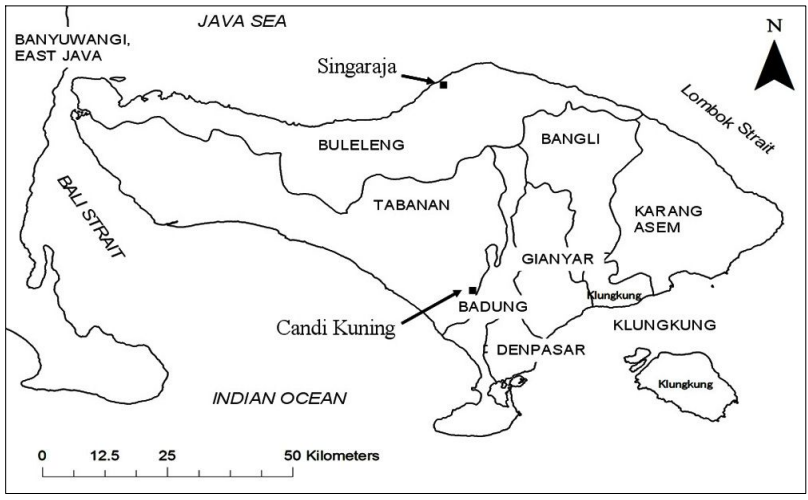

Fig. 1. Map of Bali Island. Candi Kuning and Singaraja are major survey sites.

(3,142 m) and Mt. Batur (1,717 m). The last eruption of Mt. Agung was recorded in 1963 and resulted in serious disturbance, killing 1,148 people. For the Balinese, Mt. Agung and Mt. Batur are sacred sites and homes to Gods. Volcanoes have played a crucial role in the natural history of the island and have a positive impact because they have created fertile land for agriculture. According to official documents, most agricultural land, 164,749 ha, consists of areas with $15 \sim 40 \%$ slopes. Currently, Bali contains about 130,686 ha. (or $23.20 \%$ of the total island area) of tropical forest, which is dominated by lowland tropical forest rich in terms of plant species. An additional 3,012 ha are covered by angrove and swamp forests. The office for forest protection and conservation was established in 1970 and currently controls an area of about 24,430 ha, including a national park and other protected areas (Pemprov Bali 2006). The Bali Barat National Park (19,002 ha.) plays an important role in the Bali Starling Leucopsar rothschildi conservation program, and is also home to other protected animals, including Cervus timorensis, Bos javanicus, Felis marmorata, and Manis javanicus (Whitten et al. 1996). The pristine tropical forest and biodiversity are a growing tourist attraction. In 2003, the park was visited by 65,846 domestic and 15,226 international tourists (Pemprov Bali 2006).

Beside its natural richness, Bali is also rich in culture and traditions. The Balinese believe that peace is attainable only when people respect the three harmonious relationships that are known as the Tri Hita Karana doctrine. The three causes for happiness and human prosperity are based on the three elements, namely belief in God, the environmental realm and the social realm. Humans should live in harmony with the Gods, build relationship among community members and appreciate and respect natural environments. These three fundamentals of welfare and security are widely applied in Balinese life, and these beliefs are transferred from generation to generation (Pamela and Carmencita 2005, Picard 2006).

The attractiveness of Balinese customs and Bali's luxurious envi- 
ronment has drawn large numbers of western travelers to Bali. It is quite difficult to define the initial stage of tourist visitation to Bali. However, the Netherlands Indies Tourism Bureau recorded about 213 tourist visits to Bali in 1924. This number reached 1,428 in 1929, and about 3,000 in 1934. In recognition of the potential of tourism to generate income for the nation, the first tourism planning for Bali was proposed in the 1970s. The Indonesian government invited SCETO (a French consultant) to make a feasibility study and formulate a tourism plan. The planning exercise revealed that Balinese culture was the main driver for Bali tourism. The planning also recommended that the southern end of the island, encompassing Sanur, Kuta and Nusa Dua, be developed as a tourism zone (Picard 2006).

Soon after tourist infrastructure and accommodation were established, this area grew as a world tourism center. In the 1980s, hotel numbers grew rapidly, providing for the basic need of tourist accommodation. The coastal area became crowded by visitors and tourism fever slowly expanded into every corner of the island. In the center of the island, tourism grew in the Ubud area, and stimulated the establishment of cottages and hotels on the slopes of Mt. Agung and Mt. Batur. Tourism has become the main industry in Bali, with numerous consequences. As the sustainability of tourism to the area and the quality of life for the local people depend on the ability of planners to maintain Bali as a piece of paradise on earth, discussions about tourism and sustainable development receive a lot of attention. One of the more notable projects was the Bali Sustainable Development Project, which was funded by the Canadian Government through CIDA. It was implemented in 1989 1996 with the goal of developing institutional capacity and human and societal resources in order to promote and enhance sustainable development on this fragile island (Ringer 1997).

From the end of the twentieth century to the beginning of the new millennium, Bali was under high pressure due to a number of incidents. Fantastic growth in tourism during the 1970s declined sharply after the Indonesian Financial Crisis in 1997 and the Bali bombings in 2002 and 2005, contributing to negative growth in tourism (Pemprov Bali 2006). Other problems emerging included increasing damage to natural resources, the spread of diseases, social clashes and changes in attitudes deemed detrimental to the local culture (Prideaux et al. 2003). The Balinese culture and people are also undergoing a rapid change due to myriad external influences (Picard 2006). Western and Balinese scholars, as well as the indigenous community, now debate about the desirability of further growth in tourism due to its negative economic, social, environmental and cultural impacts. The conclusion of these discussions and debates among Balinese alarmed by these changes is often that strenuous efforts must be made to renew the Balinese culture and faith, which have declined in response to external influences. Ajeg Bali is often invoked as a local spirit that can mitigate bad influences. Essentially, it is the Balinese way of trying to preserve their culture and traditions in the globalizing world. Although Balinese perceptions of the Ajeg Bali varies (Pamela and Carmencita 2005), it is clear that their strong desire to preserve Balinese tradition is intact.

Ajeg Bali can be interpreted as a societal vision for culture and nature conservation, and therefore it has become an important element in plans for sustainable development. One of the fundamental, yet little discussed, aspects of Ajeg Bali, is the use of Balinese knowledge to manage resources and manipulate land for sustainable use. Ajeg Bali tries to seek and reenact past Balinese experiences, including cultural and environmental management practices. An essential consequence of the Ajeg Bali vision is that ethnoecological practices have become important. Ethnoecology deals with the study of the wise uses of resources by the indigenous community and it has recently been widely explored and discussed as a method to achieve sustainable development (Martin 1995). Local wisdom and indigenous traditions have been successful in creating and maintaining balanced ecosystems for a long time. While the Ajeg Bali vision has as its chief objective the conservation of Balinese traditions, it may also be integrated into the development of sustainable tourism. Conversely, Ajeg Bali provides moral guidance as to how tourism should coexist with the Balinese culture and traditions that have allowed Bali Island to remain a garden paradise, reflecting its environmental balance and integrity.

\section{CULTURAL LANDSCAPES}

In many parts of the globe, humans have been interacting with nature for a long time. Interactions between humans and nature produce cultural landscapes in every corner of the world (Plachter and Rössler 1995, Hong et al. 2008). Diverse people living in different environments and with different cultures have developed strategies to survive in their landscapes, creating numerous forms of such landscapes as a result of their efforts to sustain their communities. These human-modified landscapes are often regarded as part of nature and humans therefore become a component of nature. Indeed, cultural landscapes are inscribed on the world heritage list in the World Heritage Convention 1992 (Fowler 2003), reflecting their significance in sustainable local and regional development for current and future generations.

In Bali, spatial planning and traditional landscape design are based on Tri Angga as a principle organization of space. The spatial management and space division concepts of the Balinese divide landscapes, both vertical and horizontal, into three levels: high, 
middle and low. On the vertical axis, Tri Angga views mountains as the highest and most sacred of sites, followed by land and human settlement in the middle, with the sea in the lowest position. In the middle of Tri Angga are lowlands areas with attributes such as valleys, rivers, human settlements, and agriculture complexes. This level is dedicated to human habitats and, eco-physically, to widely distributed cultural landscapes. Beach and marine environments are the lowest in Tri Angga teaching. Today, they are the most developed areas for tourism, where most hotels and othere tourist accommodations are established.

On a horizontal axis, Tri Angga teaching is manifest in rural spatial organization, which is divided into three categories, with the village temple area (Kahyangan tiga) as the highest/ sacred part, the village's inhabitants area (Pawongan/Krama Desa) as the middle part, and the village's immediate environment (Palemahan/Karang desa) as the lowest part. Village temples and open spaces that function as parks established at the north corner of a village represent the human-God relationship in the Tri Hita Karana doctrine. A settlement (Umah), official and public buildings (i.e., Bale Wantilan, Bale Kulkul), a palace (Puri), roads and open spaces (Alunalun) are placed; these structures are dedicated to dwellers' activities. In the Tri Hita Karana concept, such areas represent the relationship between people. In the south of the village are markets, public bathing spaces, sports yards and a cemetery, which reflect the relationship between humans and their environment. The cosmological teachings provide guidelines for society on how to use and manage the environment in sustainable ways, using the Tri Hita Karana doctrine (Dwijendra 2003, Yudantini 2003, Samadhi 2004).

Perhaps the most obvious characteristic of Bali, as well as other rural tropical areas, is the abundance of agricultural fields. The large areas of fertile land and abundant water resources have permitted paddy cultivation for a long time, and rice cultivation has become one of the main economic activities in Bali. In many parts of the island, such as sloping upland areas, the land is fragile and sensitive to disturbance as a result of agricultural activities. Terraces have been created as a strategy to permit the use of hilly and sloping environments (Whitten et al. 1996). Recent research suggests that the use of terraces promotes soil conservation by minimizing the rapid surface runoff of irrigation water, reducing landslide risk, and mitigating soil erosion (Lansing 2000). Terracing is common in Asian countries, but Balinese paddy terraces show special features because terrace design is integrated into the culture and faith.

In Bali, paddy terraces have been developed over a period of more than a thousand years and the keys to their success are the Subak and water temple systems (Lansing 2000). Farmers in Bali organize their community into a Subak, an indigenous farmer organization consisting of a group of farmers that share a common water supply, manage irrigation together, and organize cultural activities. In this system, farmers meet annually in regional water temples to determine cropping patterns and irrigation schedules, which have important effects on both water use and pest control. The terraces could not be sustained by continuous rice cropping, so this careful management permits the successful management of this delicate ecosystem. In the past, disturbance of such ethno-ecological mechanisms has been reported to contribute to chaos in water scheduling, pest population explosions and crop losses. The successful management of terraces using the Subak system distinguishes Balinese terrace management from other terrace management systetms (Fig. 2).

Spatial planning and management plans by the Balinese create opportunities for biodiversity conservation. For instance, the declaration that a particular zone is sacred leads to low disturbance due to anthropogenic factors, and provides opportunities for biodiversity to survive. The sustainability of such processes is high as this system is bound to faith and the cultural system (Samadhi 2004). The harmonious nature of the Balinese cultural landscape therefore presents an excellent model for the achievement of sustainable development. UNESCO has proposed the Balinese model of paddy terracing for the world heritage list. In fact, such cultural landscapes nowadays have become tourism attractions in and of themselves (Fowler 2003).

\section{ETHNOECOLOGY AND TOURISM AUTHENTICITY}

The image of a destination is the main factor affecting tourists' choice of destinations, and is also a crucial factor in determining tourist satisfaction (Baud-Bovy and Lowson 2002, Fyall et al. 2005). In past decades, tourism planners have recognized that authenticity is one of most significant factors that promote tourist arrivals

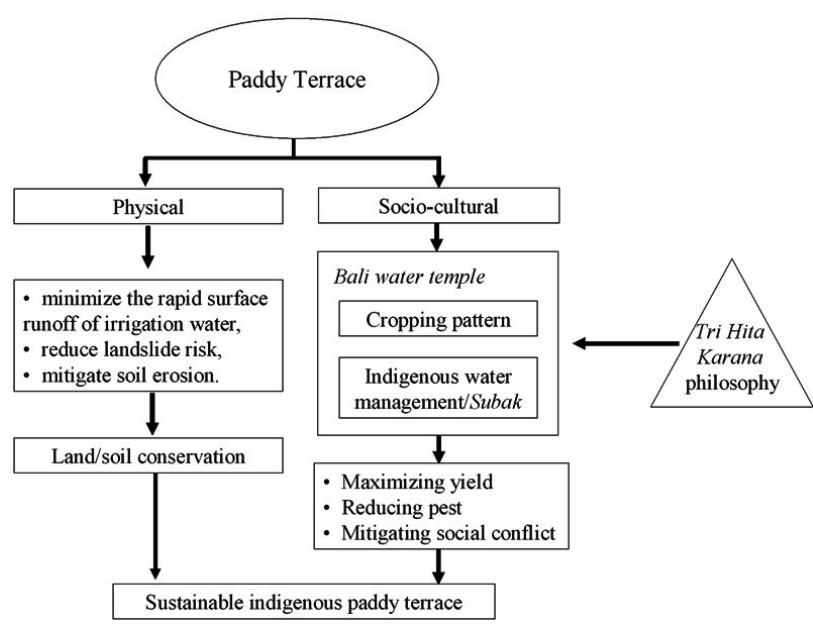

Fig. 2. The character of the paddy terrace as a cultural landscape in Bali bound to the Balinese philosophy called Tri Hita Karana. 
(Wang 1999, Yeoman et al. 2007, Hakim et al. 2008), particularly in the recent tourism market, where new generations of tourists have a high level of education, pay a lot of attention to conservation issues, are aware of indigenous societies and seek genuine natural attractions (TIES 2000). However, debates about authenticity in tourism have been continuous and so far there is no consensus about the basic concept behind authenticity (Wang 1999). However, generally it is accepted that authenticity is associated with the indigenous society and its cultural attributes. The term "authenticity" is used to represent the originality of a particular destination to tourists who desire an experience involving the indigenous people, indigenous works of art, artifacts, indigenous rituals and so in a particular tourism destination.

The concept of authenticity is often applied to heritage tourism and ethnic/tribal-oriented attractions (Fyall et al. 2005, Swarbrooke 2006). In this regard, reports about a destination's authenticity conclude that spatial elements of a destination are essential to provide an authentic experience (or tourist experience) of the toured object. Because authenticity is the concept originating in the condition of modernity and has been conceptualized and perceived by western/tourist/non-indigenous communities as the typical character of the particular area, the authentic destination should be able to represent the "sound of place" for every touring program and object visited (Yeoman et al. 2007). This implies that the preservation of indigenous environments is crucial in order to define destination authenticity. Moreover, Hall (2007) argues that the integration of environmental components and physical and social components of every day life of the place is also important. Loss of such integration can lead to dishonest representation of the destination.

Community involvement is necessary to build and enhance destination authenticity (Yeoman et al. 2007). In the socio-ecological context, authenticity is easily understood as an interaction between humans and nature that creates landforms with their own typical characters. Therefore, obtaining consistent support from the local society for genuine landscape preservation is a prerequisite for the protection of destination authenticity. While there have been numerous official regulations and management guidelines, informal regulation bound to the faith/cultural system is often more effectively implemented (Dudley et al. 2005). However, few examples of effective informal regulation are available to guide future efforts. Moreover, many places have been modernized and lost or seen major alterations in their faith/cultural systems.

In Indonesia, the Balinese successfully demonstrate how a community can support and preserve authenticity and therefore support a tourism industry. The key lies in community appreciation of indigenous knowledge and ethnoecological practices as a way to utilize land and resources. Since ethnoecology is bound to the reli- gious/faith system as well as the culture, such practices are appreciated and preserved among Balinese generations. As a result, the characteristics of the Balinese regional landscape are conserved in traditional ways and contribute to the island's authenticity (Fig. 3). In many parts of Bali, the practice of ethnoecology is widely applied on scales ranging from households to communal stages, reflecting the significant participation of society in the preservation of indigenous values (Siregar et al. 2004, Picard 2006).

In Bali, besides contributing to the creation of an amazing cultural landscape, ethnoecology also provides opportunities for landscape rehabilitation in its original sense: minimizing impure landscape design, and strengthening the idea of the "Island of Gods", which contributes to Bali's authenticity as a destination. In the Ekakarya Botanical Garden, for example, ethnoecology has been used to guide park landscaping for conservation programs and interpretive programs for ecotourism (Siregar et al. 2004). Balinese ethnoecology includes a form of garden design that is known to produce most dynamic and richest gardens in the world. The composition of the garden, with its trees, shrubs, herbs, flowers, and offering temple (Padmasari), is arranged following Tri Hita Karana philosophy. The home gardens are characterized by offering plants (i.e. Plumeria sp., Musa sp., Michelia champaca, Cananga odorata, Theveta peruviana, Pandanus amrillyfolius, and Rosa sp.). The high diversity of plants and their arrangement, the presence of Padmasari, and the interaction between gardens and humans are the most important characters of a Balinese garden landscape.

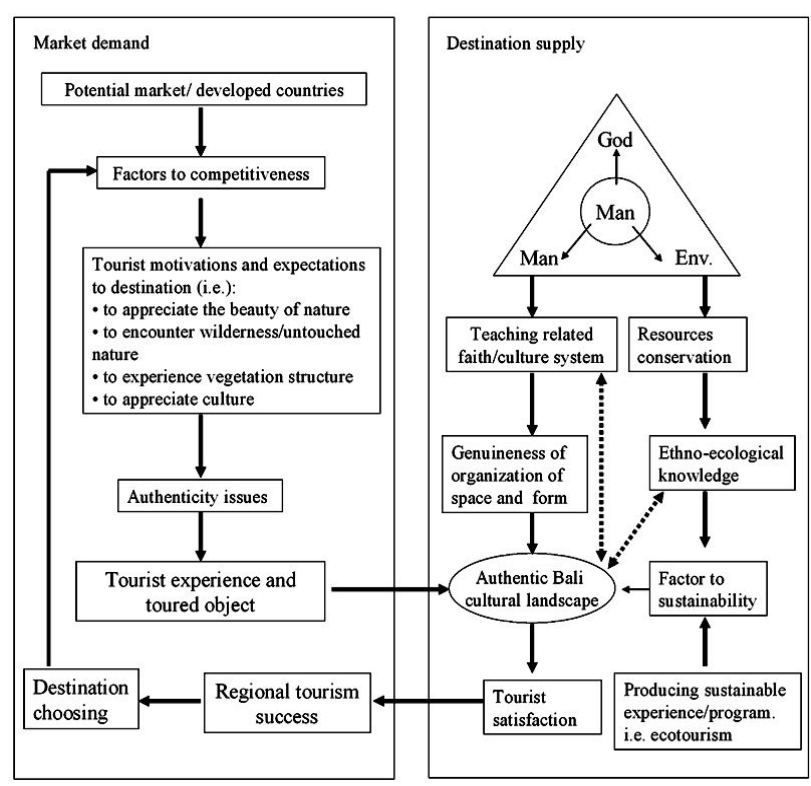

Fig. 3. Conceptual framework illustrating how ethnoecology contributes to regional tourism destination authenticity (dotted lines indicate control and mechanism). 

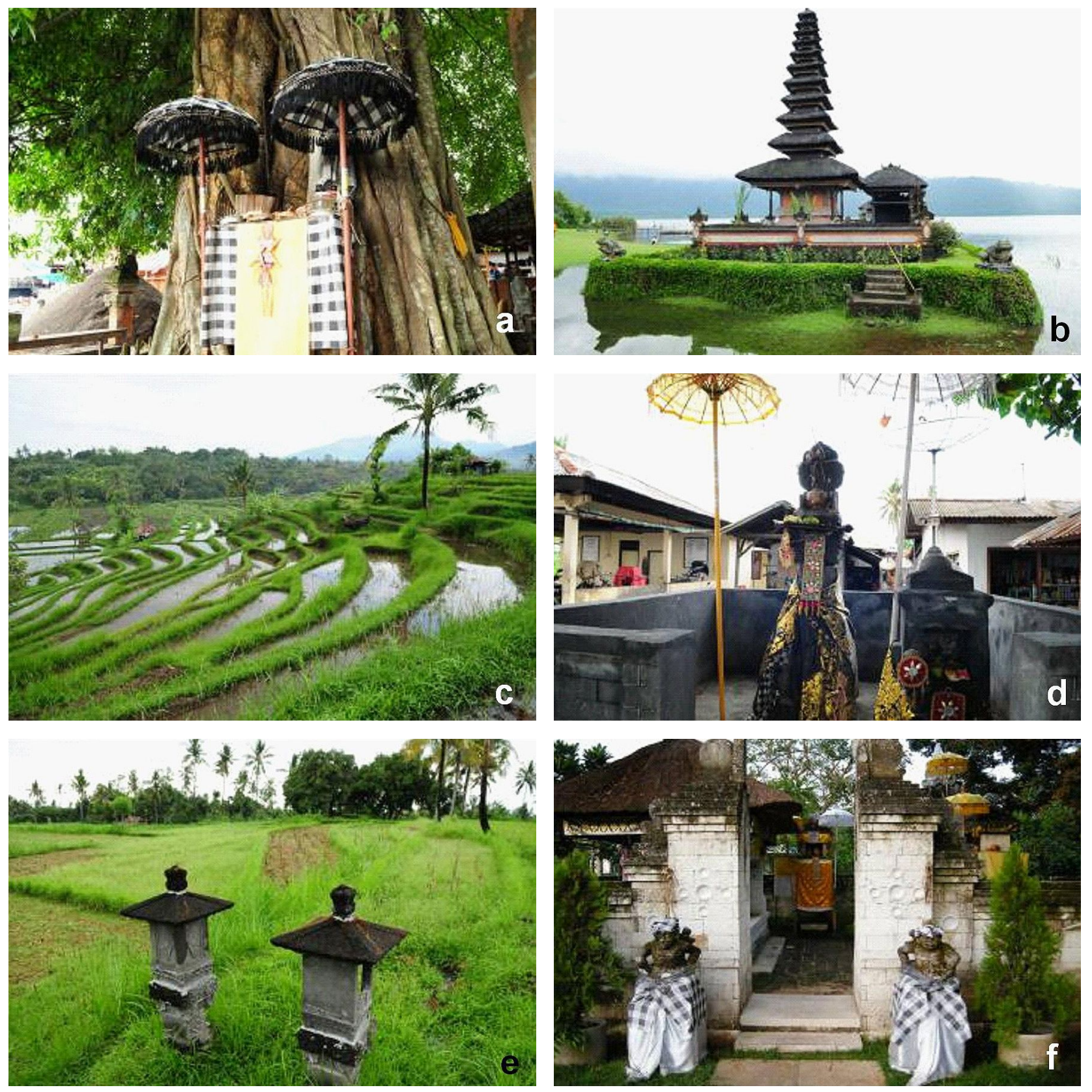

Fig. 4. Balinese cultural landscape based on the philosophy and indigenous knowledge of Tri Hita Karana (photo by SK Hong). a: Large holy trees and a sacred place marked with Balinese colored cloth on the roadside from Denpasar to Singaraja. b: The Ulun Danu Temple is a Balinese Hindu Temple located in Beratan Lake in the Candi Kuning countryside. The water body (lake) is a fertility source that confers prosperity in Balinese philosophy, c \& e: A terrace paddy landscape near Singaraja and a small pagoda embodying the Gods' support to the water supply and land fertility, d \& f: Sacred places for prosperity in the Singaraja coastal village.

\section{DISCUSSION AND CONCLUSION}

With the recent increase in tourism oriented around authentic experiences of culture and nature, many countries that are poor, but rich in cultural and natural resources, have seized the opportunity to use the tourism sector as a machine for growth. To be successful, countries must be able to define their own assets in a way that meets tourists' demands. As the current generation of tourists includes sophisticated travelers that pay a lot of attention to cultural and natural issues, accurate identification and description of a country's cultural and natural assets is an important step in tourism planning.

Bali is a small island where the future of tourism ultimately 
depends on the preservation of their rich and harmonious culture and natural landscapes. While tourism can potentially damage the island's ecosystems, the indigenous philosophy promotes sustainable development in several ways. First, the Balinese philosophy provides rules and guidelines by which humans can live in the biosphere in a sustainable manner. Second, the Balinese system is able to facilitate indigenous knowledge preservation and its application in the community. Nowadays, indigenous techniques such as ethnoecology are widely practiced to manage the island's resources, and significantly contribute to the sustainable development agenda (Martin 1995, Dudley et al. 2005, Mercer et al. 2007).

The cultural landscape represents evidence of community appreciation of the indigenous philosophy and the application of ethnoecology. As a result, the Balinese cultural landscape is unique, and has gained Bali a reputation as a paradise on earth. Community involvement/participation and brand identity are needed to build destination authenticity (Yeoman et al. 2007), and Bali's authenticity has emerged as a community product as a result of the ethnoecological approach taken by the local society, and is a key to its competitiveness.

The authenticity of Bali, however, could become degraded in several ways. First, changes in national policy regarding agriculture and a decline of ethnoecological practices due to modernization and the introduction of technology may threaten Balinese traditional practices. In the past, the green revolution and capitalized farming have been threats to the Subak and the water temple system, disrupting farming in some areas, and degrading the cultural landscape in Bali. Second, the tourism boom and increasing tourist demands to encounter Bali's authenticity can lead to the misrepresentation of destinations (Yeoman et al. 2007, Hall 2007). Ethnoecology can play an important role in preventing these problems and as a mechanism to control the authenticity of Bali as a destination, because ethnoecology comes from the traditional methods of resource management and therefore produces and reproduces the real product (Martin 1995). The objective is clear, preserving Bali's genuine landscape. Therefore, there is clearly an important role for ethnoecologists in tourism planning.

While traditional perspectives in ethnoecology generally focus on medical plants, home garden structure and agriculture practices (Martin 1995, Hakim 2008), this study shows that applied ethnoecology can also contribute to the tourism industry as a result of its ability to represent the Balinese cultural landscape. We recommend that the application of indigenous knowledge be encouraged with the objective of enhancing regional capacity. Ethnoecological practices produce an authentic cultural landscape, which can make the destination more attractive to tourists. Promoting such practices also generates indigenous society support for the sustainable use of resources. These are the factors that guide the tourist industry towards the development of a sustainable and competitive destination.

\section{ACKNOWLEDGMENTS}

This research was partially supported from Korea Research Foundation (KRF-2005-005-J02701) to the SK Hong.

\section{LITERATURE CITED}

Baud-Bovy M, Lowson F. 2002. Tourism and Recreation: Handbook of Planning and Design. Architectural Press, Oxford.

Dudley N, Higgins-Zogib L, Mansourian S. 2005. Beyond Belief: Linking Faith and Protected Areas to Support Biodiversity Conservation. World Wide Fund for Nature, Swaziland.

Dwijendra NKA. 2003. Perumahan dan pemukiman tradisional Bali. J Pemukiman Natah 1: 8-24.

Fyall A, Garrod B, Leask A. 2005. Managing Visitor Attraction: New Directions. Elsevier, Oxford.

Fowler PJ. 2003. World Heritages Cultural Landscape 1992-2002. World Heritages Paper No. 6. UNESCO World Heritage Centre, Paris.

Gunn CA, Var T. 2002. Tourism Planning: Basic, Concepts and Cases. $3^{\text {rd }}$ Ed. Roudledge, London.

Hakim L. 2008. The cultural landscapes of the Tengger Highland, East Java. In Ecology in Asian Cultural Landscape (Hong SK, Wu J, Kim JE, Nakagoshi N, eds). Springer, Tokyo. (in press)

Hakim L, Hong SK, Kim JE, Nakagoshi N. 2008. Tourism and cultural landscape at the Tengger, East Java, Indonesia: The implications for ecotourism planning. Kor J Env Eco 22: 207-220.

Hakim L, Hong SK, Kim JE, Nakagoshi N. 2007. Nature-based tourism in small island adjacent to Jakarta City, Indonesia: A case study from Kepulauan Seribu. J Kor Wet Soc 9:31-46.

Hall CH. 2007. Response to Yeoman et al: The fakery of 'The authentic tourist'. Tour Manage 28: 1139-1140.

Hong SK, Nakagoshi N, Fu BJ, Morimoto Y. 2008. Landscape Ecological Applications in Man-Influenced Areas: Linking Man and Nature Systems. Springer, Dordrecht, The Netherlands. 535p (Paper book Edition).

Lansing F. 2000. Foucault and the water temple. Critiq Anthrop 20: 309-318.

MacCannell D. 2008. Why it never really was about authenticity. Society 45 : 334-337.

Martin GJ. 1995. Ethnobotany: A Methods Manual. Chapman and Hall, London.

Mercer J, Dominey-Howes D, Kelman I, Lyod L. 2007. The potential for combining indigenous and western knowledge in reducing vulnerability to environment hazard in small island developing states. Env Haz 7: 245-256.

Pamela MA, Carmencita P. 2005. Ajeg Bali: Multiple meanings, diverse agendas. Indon Mal Wor 33: 239-255.

Pemprov Bali. 2006. Profil Daerah Bali. Pemerintah Provinsi Bali, Denpasar. 
Picard M. 2006. Bali, Pariwisata Budaya dan Budaya Pariwisata. Kepustakaan Pupuler Gramedia, Jakarta.

Plachter H, Rössler M. 1995. Cultural landscape: Reconnecting culture and nature. In Cultural Landscapes of Universal Value: Components of a Global Strategy (von Droste B, Plachter H, Rössler M, eds). Gustav Fischer in cooperation with UNESCO, Jena, pp 1518.

Prideaux B, Laws E, Faulkner B. 2003. Events in Indonesia: Exploring the limits to formal tourism trends forecasting methods in complex crisis situations. Tour Manage 24: 475-487.

Ringer G. 1997. Bali: Balancing environments, economy and culture. Ann Tour Res 24: 485-502.

Samadhi TN. 2004. Making cosmo-religious landscape: The design of Balinese town's civic centre (Bali, Indonesia). Hab Intern 28: 103122.

Siregar M, Siregar HM, Sumantera IW, Wiswastra IGNA, Sutara PK, Lestari WN. 2004. Konservasi Tumbuhan Upacara Agama Hindu.
KR Ekakarya Baturiti, Singaraja.

Swarbrooke J. 2006. The Development and Management of Visitor Attractions. Elsevier Butterworth Heinemann, Amsterdam.

TIES. 2000. Ecotourism Statistical Fact Sheet. The International Ecotourism Society.

UNWTO. 2007. Tourism Highlights 2007 Editions. http://www.unwto.org. Accessed 8 August 2008.

Wang N. 1999. Rethinking authenticity in tourism experience. Ann Tour Res 26: 349-370.

Whitten T, Soeriaatmadja RE, Afif SA. 1996. The Ecology of Java and Bali. The Ecology of Indonesia Series Volume II. Periplus, Singapore.

Yeoman I, Brass D, McMahon-Beattie U. 2007. Current issue in tourism: The authentic tourist. Tour Manage 28: 1128-1138.

Yudantini NM. 2003. Balinese traditional landscape. J Pemukiman Natah 1: 65-80.

(Received January 19, 2009; Accepted February 19, 2009) 